\title{
Research of Practice Teaching System for Training Civil Engineer
}

\author{
Sun Jianmin ${ }^{1,}$, Zou Jiting ${ }^{1, b}$ and Gao Linghua ${ }^{1, c}$ \\ ${ }^{1}$ Beijing University of Civil Engineering and Architecture, Beijing, 100044, China \\ ajianminsun@tom.com, bzoujt61@163.com, ${ }^{c} 1273055852 @ q q . c o m$
}

Keywords: civil engineering specialty, practice teaching, Engineer training, teaching reform, training mode.

\begin{abstract}
The effect of the practice teaching plays a crucial role in improving teaching quality and implementing training target of innovative talents. In the implementation process of the training plan for civil engineering specialty engineers, it is explored that the practice teaching link in the cultivation of practical ability, innovation and design ability, comprehensive service ability for civil engineering talents in local colleges and universities. According to the analysis about the features of civil engineering specialty, that innovation link of practice teaching, construct practice teaching system of training the engineering ability and innovation ability as the goal are designed and innovative practice teaching method of training civil engineering specialty engineers is explored.
\end{abstract}

\section{Introduction}

Higher education is an important means of cultivating innovative talents, and practice is the source of innovation. in each teaching link, students can be provided by the practice teaching with an important way that transforms theoretical knowledge into behavior ability. Practice teaching is an important link to cultivate students to integrate theory with practice, the basic knowledge they have learned is fully used to make engineering design, and strengthen the manipulative ability. It is also an important teaching link to cultivate the students' creative ability, development ability and the ability to analyze and to solve problems independently to improve students' comprehensive quality[1-4].

As a base of civil engineering talents cultivation, it must be suited to the needs of the industrial development and the demand of the enterprise. In the field of engineering construction, the project legal person responsibility system, bidding system, project supervision and evaluation system are being established and implemented gradually; related laws and regulations in this field are being constantly enriched, updated and improved; and international project management is becoming more and more [5-6]. It is required that the personnel in engineering construction field on the one hand,should master knowledge of civil engineering technology, on the other hand, they have to know the industrial rules and regulations and management knowledge, to have economic mind and good foreign language level at the same time.

Due to the specificity and the complexity of the engineering construction, civil engineering talents should be well master of the basic theory and professional knowledge. With professional knowledge that meet the requirements of engineering knowledge of engineering economics and management, practical engineering problems are able to be correctly judged and solved, the complicated relationship between engineering and society can be understood and cooperation with personnel of different disciplines can be realized. Therefore, civil engineering colleges and universities are needed to develop senior talents that can adapt to structure adjustment in construction enterprise, be familiar with project management and possess innovation ability.

\section{Practical Teaching System Aimed at Training Engineering Ability and Innovation Ability}

Departments' such as the ministry of education several opinions on further strengthening the educational job of university practice (teach education [2012] no. 1 files) [7] pointed out that: Each college should combine professional characteristics with requirements of personnel training, practice teaching standards drawed up classified and the proportion of practice teaching increased is to ensure 
that the Tech majors proportion is not less than 25\%. Education departments must strengthen the inspection management and the educational work team in colleges and universities practice it.

Strengthen the engineering ideology education. Civil engineering specialty in architecture colleges and universities engage the job closely related to the engineering practice, so in the process of undergraduate education and teaching, it has important meaning in engineering education for students. In the process of engineering education, it needs to break the bondage of traditional thinking, and stimulate students' creation enthusiasm, cultivate the innovation consciousness, innovation ability and engineering practice ability of engineering and technical personnel. All the teaching activities and research center the engineering, from the project, rely on engineering and guide the engineering, project handover [8].

Strengthen the internship practice. Practice teaching includes the cognition practice, course practice, production practice and graduation practice, and each link is interlocking and progressive.

Cognition practice of civil engineering specialty is students before entering the professional course study, access the teaching process of professional practice for the first time. It is through the interpretion from engineering and technical personnel and teacher's explanation, that to make the students about architectural structure, engineering structure and civil engineering construction to establish certain perceptual knowledge, to lay the foundation for students to learn the professional course.

Production practice is an important link in practical teaching, is verious practic carried by students in the whole construction process on e, is a necessary complement to classroom teaching and a drill students participated actually before graduation.

To cultivate the ability of comprehensive innovation design. Positive competition events can also strengthen the exchanges and cooperation between the colleges and universities and achieve common progress. Students are encouraged to participate in CupChallenge, business competition, architectural design competition, structure, mechanical innovation design competition, mathematical modeling race, such as robot competition comprehensive games.

The scientific research results are tranformed into research papers and course case, specialized personnel, for students to collect and sort out teachers' scientific research achievements, patent project, students' mathematical model dissertation, science and technology innovation article to inspire the students'new study idea. Through the reading of the publication and the course teached, the student are closely feel of innovation, stimulated with innovation potential. Emphasizeing the research platform served for the teaching and students are allowed to participate in teachers' scientific research project is an effective way to improve students' ability for the scientific research practice link.

\section{Civil Engineering Class Place to Explore Innovative Practice Teaching Method}

Experimental teaching mode.Laboratory is the base of teaching and scientific research, is the practice classroom of training innovative talents. First of all, the experiment project has to realize the shift from verification to skilled and innovative experiment. For skilled, innovative experiment, mainly made by the students themselves, teachers' guide, to discuss and solve the problem. Secondly, set up a special experiment to realize the shift from single course into professional comprehensive experiment. The experiment belong to single course are separated from course teaching and set up to be special experiment which is checked independent, to change contempt problem for the experiment teaching link before. Such as the experiment content in engineering materials, engineering concrete structure, steel structure course is regard as a professional comprehensive experiment course.

Teaching methods of course practice.Course practice may make the students master the courses studied through research, visits, lectures, operations, discussion, homework, evaluation and other forms. In selecting topic process, aiming at the course content, the teacher must try to be really writes really do, in order to improve the students' ability as the starting point and ultimate goal. The method of assessment results tied with honor can be used to motivate students treat it seriously. 
The method of oral examination in assessment is adapted to avoid some students copying others' achievements. Serious appraisal system is an effective way to improve the teaching effect.

Graduation design teaching methods coalition of college and enterprise. In order to enhance students' engineering practice ability and quality, it must make full use of university-enterprise cooperation platform, formulate combined teaching measures, sign the agreement with large-scale backbone enterprises on joint teaching, hire engineer with high academic level and rich practical experience and management ability as the practice teacher for students to explore the new personnel training mode of practice teaching.

Through the practice in stages, joint graduation design in the enterprise, students will be familiar with basic methods of civil engineering design and construction and project management and improve the comprehensive ability to use knowledge. For understanding the engineering practice, cultivating engineering comprehensive ability such as profession quality, analysis ability, communication ability, unity cooperation ability, management ability, then students have ability to independent engage in a direction in the field of civil engineering like project design, construction, operation, management and decision-making, to meet the needs of future technology development and social progress, to be outstanding talent with practical ability, innovation ability, international vision and leadership consciousness infuture.

Innovation practice teaching mode. A research-type learning and innovative experiment plan is set up to strengthen the open experiment, then to encourage college students to participate in teachers' scientific research project or related scientific research practice of design and research institute, to increase college students' extracurricular innovation credit requirements as well as to the excellent students, such as special immortal the tutorial training policy, to construct the college students' innovative ability training system has its own characteristic, to strive to cultivate students' innovative ability and scientific literacy in the civil engineering college [9].

Professional practice teaching is an important link to cultivate and improve the civil engineering students' comprehensive ability and quality, is the validation, complement and expands for the theory teaching. Through the construction of innovative practice teaching links, the cultivation of engineering ability and innovation ability of students majoring in civil engineering specialty will be ensured, as shown in fig. 1.

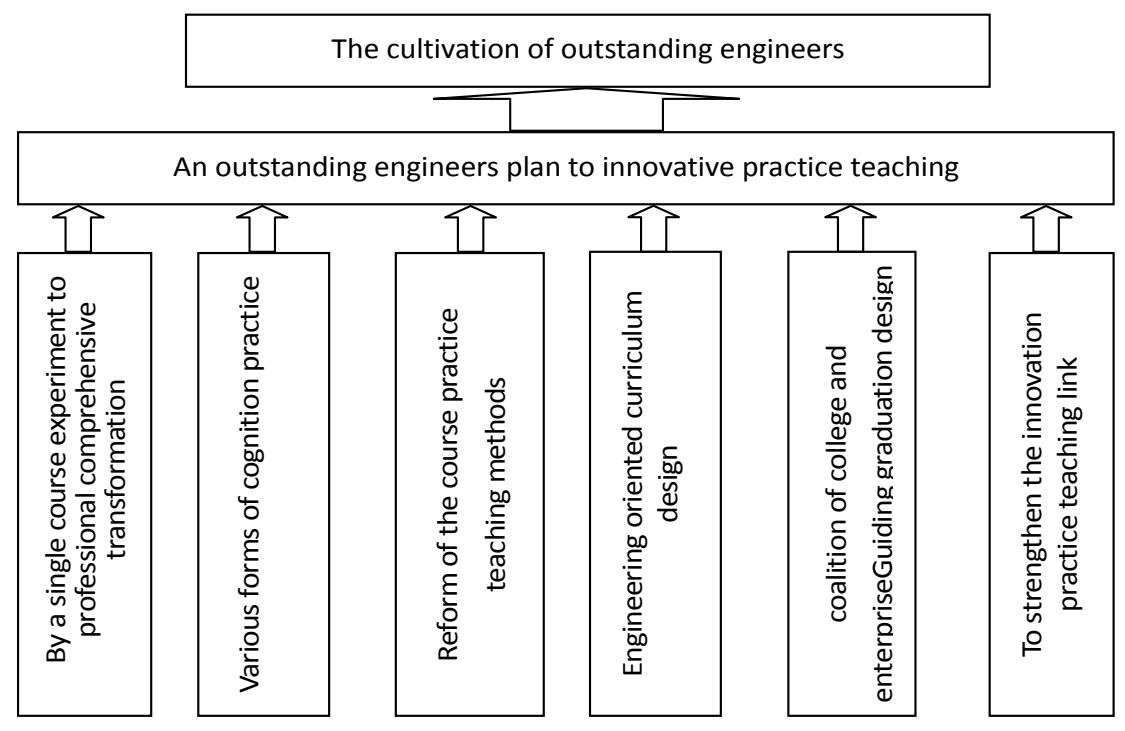

Fig. 1 Innovative practice teaching link building

\section{Conclusions}

Cultivation of civil engineering talents need to combine with engineering construction field and social practice, not only practice education, but also personnel quality need to be recognized by industry and society. Therefore, cultivation of civil engineering talents must meet the demands of 
construction field and the society. Reforming of engineering education concepts, building the mode of training for civil engineering talents for outstanding engineers' plans, and striving to improve the civil engineering talents practical application ability, innovative design ability and comprehensive service ability is the main task of training excellent engineer in construction field.

For analysis of the characteristics of civil engineering specialty, the training system of senior talent with innovative ability must be strived to build who adapts to the structural adjustment construction companies and be familiar with the project management. It is aimed at cultivating students' innovation ability and constructing a practice teaching system to cultivating students' engineering ability and innovation ability.

Practice teaching is an important link to train and improve the comprehensive ability and quality of students which majoring in civil engineering. Reform the teaching method of practice is a key to impact the reform of practice training mode and personnel training model. Through the construction of innovative practice teaching, the education method of innovation and practice t must be explored in local universities and colleges of civil engineering.

\section{Acknowledgements}

This work was financially supported by the Education and Teaching Research Project of China Construction Education Association (2013060) and the High School Education and Teaching Reform Project of Beijing Municipal Education Commission (2013148).

\section{References}

[1] Qingming Xie. On the Theory Basis of the Model of CDIO Education: Education and Occupation. 26(2010), p.184-185.

[2] Shibing Wang, Haixia Qie, Jianxing Yu. Concept and Practice of Higher Engineering Education Reform---- In Massachusetts, Berkeley, Purdue, Tianjing University as Examples [J]. Research on Higher Engineering Education. 1 (2011), p.18-23

[3] Jianzhong Xia, Jianhua Wu. Study on Practice Teaching Excellence Civil Engineer Training. Journal of Zhejiang Institute Technology, 22 (2010) , p.387-391.

[4] Tong hao, Gang Guan, Lixin Liu. Research on the Training Mode of Professional Talent Market Demand and the Talent Localization, Civil Engineering. Journal of Lanzhou University of Science and Technology, 10 (2009) , p.53-55.

[5] Tongmei Li, Yuanfu LI, Xiongzhi Peng, Research and Practice on the Reform Scheme and Course System of Civil Engineering Specialty Talents Training, Lanzhou University of Science and Technology, 10 (2009), p.15-17.

[6] Xu Li, Nan Shen, Chunlong Yao. Exploration and Reform of Engineering Talent Training Mode base on "Excellent Engineers Plan". Computer engineering and Science, 33 (2011) , p.109-111.

[7] Ministry of education: Several Opinions on Further Strengthening the Practice of Education. (2012).

[8]Yongfeng LIU ,Pucheng PEI, Asymptotic Analysis on Autoignition and Explosion Limits of Hydr ogen-Oxygen Mixtures in Homogeneous Systems,International Journal of Hydrogen Energy,31( 2006),p.639-647.

[9]Y. LIU,Y. ZHANG.Optimation Research for a High Pressure Common Rail Diesel Engine Base d on Simulation, International Journal of Automotive Technology, 11(2010), p.625-636 